\title{
MODERNISASI ALAT TANGKAP DAN PENGARUHNYA TERHADAP NELAYAN TELUK PRIGI KAB TRENGGALEK TAHUN 1982-2006
}

\author{
Khoirun Nikmah
}

Dosen Jurusan Tadrsi IImu Pengetahuan Sosial, fakultas Tarbiyah dan Ilmu Keguruan, Institut Agama Islam Negeri Ponorogo, Jl Pramuka 156, Po.Box 116 Ponorogo 63471, kanimarurun@gmail.com

\begin{abstract}
ABSTRAK
Artikel ini bertujuan untuk menganalisis modernisasi alat tangkap dan pengaruhnya terhadap nelayan Teluk Prigi Kab Trenggalek pada tahun 1982-2006. Dalam temporal tahun 1982-2006, nelayan Teluk Prigi mengalami beberapa perkembangan perubahan alat tangkap. Mereka yang mulanya menggunakan alat tangkap tradisonal kemudian menggunakan alat tangkap yang lebih modern. Ada juga nelayan yang tetap menggunakan alat tangkap tradisional karena kendala modal.
\end{abstract}

Kata kunci: modernisasi, alat tangkap, Prigi, nelayan

\section{ABSTRACT}

This article aims to analyze the modernization of fishing gear and its influence on the Prigi Bay fishermen in Trenggalek Regency in 1982-2006. In the 1982-2006 temporal, Prigi Bay fishermen underwent several developments in fishing gear changes. Those who first used traditional fishing gear and then used more modern fishing gear. There are also fishermen who continue to use traditional fishing gear because of capital constraints.

Keywords: modernization, fishing gear, Prigi, fishermen

\section{PENDAHULUAN}

Secara garis besar, banyak masyarakat di pesisir selatan bergantung pada sector kelautanmeskipun tidak meninggalkan basisi agararis. Tidak semua masyarakat pesisir pantai mereka mencari nafkah di laut. Keengganan masyarakat pantai selatan tidak memamafaatkan potensi lautnya dipengarui oleh budaya. Kepercayaan mengenai makhluk penguasa lautan selatan atau Nyi roro Kidul dinilai sebagai sosok yang menakutkan. ${ }^{1}$ Di Prigi pun potensi lautnya pada tahun 2000an potensi laut belum dikelola secara maksimal. Prigi merupakan suatu teluk di kawasan Pantai Selatan Kabupaten Trenggalek. Teluk Prigi merupakan teluk terbesar di kabupaten ini setelah Teluk Panggul dan Munjungan. Pada tahun 1970-an Teluk Prigi baru dimanfaatkan oleh penduduk yang bermata pencaharian sebagai nelayan. Penangkapan ikan di pantai masih dilakukan dengan cara yang sederhana, salah satunya dengan menggunakan jaring yang ditarik oleh puluhan nelayan (Profil Daerah dan Kota, 2001:285). Teluk Prigi dan nelayannya memiliki keunikan tersendiri untuk diteliti. Kajian mengenai nelayan Teluk Prigi dari aspek ilmu perikanan, kelautan, dan sosiologi telah banyak dilakukan. Namun kajian dalam ilmu historis masih jarang sekali diteliti. Untuk itu penulis mencoba melakukakan kajian dari sudut penelitian historis.

Istilah modernisasi adalah suatu istilah yang kabur. Namun umumnya modernisasi dipakai menunjukkan pertumbuhan dan perubahan (Myron Winer, 1961: I). modernisasi yang terjadi pada nelayan Teluk Prigi salah satunya adalah alat tangkap mereka. Alat tangkap yang mulanya menggunakan cara tradisional, berubah menjadi alat tangkap yang lebih modern. Meskipun tidak menutup kemungkinan masih ada nelayan yang menggunakan alat tanggap tradisional sampai tahun 2004.

Dari pendahuluan di atas muncul beberapa pertanyaan peneltian yakni 1) Bagaimana proses modernisasi alat tangkap nelayan Teluk Prigi Kab Trenggalek Tahun 1978-2006? 2) Bagaimana pengaruh modernisasi alat tangkap terhadap kehidupan nelayan Teluk Prigi Kab Trenggalek pada tahun 1982-2004?

\section{METODE PENELITIAN}

Penelitian ini merupakan penelitian sejarah maritim. Sejarah maritim meneliti masalahmasalah tentang masyarakat pantai, perkembangan pelabuhan, hubungan tingkat produksi, sektor jasa, dan sebagainya (Sutejo K Widodo,2005:8). Penelitian ini menggunakan sejumlah sumber

\footnotetext{
${ }^{1}$ Susanto Zuhdi 105
} 
dalam rentang waktu 1978-2006. Sumber yang digunakan terdiri dari sumber primer dan sumber sekunder. Sumber primer menggunakan arsip Pelabuhan Perikanan Prigi dari tahun 1982-2007, arsip BPS Trenggalek dalam angka tahun 2000, serta arsip dari Dinas Perikanan dan Kelautan Kabupaten Trenggalek tahun 2002-2003. Sumber sekunder yang digunakan dalam studi ini yakni buku-buku yang membahas tentang Pelabuhan Prigi dan masyarakat nelayannya.

Sumber-sumber yang telah didapat kemudian dianalisis melalui metode sejarah dan dibantu dengan menggunakan pendekatan ilmu sosial dan ekonomi. Pendekatan ini membantu penulis dalam mendeskripsikan tentang perkembangan pelabuhan dan dampaknya terhadap kehidupan sosial ekonomi nelayan. Tahap pertama dalam penelitian ini adalah heuristik atau pengumpulan sumber. Setelah semua sumber terkumpul selanjutnya dilakukan kritik terhadap sumber tersebut. Kritik ekstern untuk memperoleh sumber yang otentik maupun kritik intern untuk memperoleh sumber yang kredibel. Tahap yang ketiga dalam penelitan sejarah adalah interpretasi. Pada tahap ini dituntut kecermatan objektif, terutama dalam hal interpretasi. Sebagai sebuah karya historiografi studi ini dibatasi oleh ruang lingkup spasial mencakup Telu Prigi, Kabupaten Trenggalek. Lingkup temporal mencakup periode 1978-2006. Pada tahun 1978 sudah banyak nelayan Prigi yang menggunakan teknologi modern beruapa alat tangkap dan armada yang digunakan. Penelitian ini berkahir pada atahun 2006 dikarenakan pada tahun tersebut penggunaan kapal purse seine sudah banyak digunakan nelayan, dan adanya sistem bagi hasil yang semakin carut marut.

\section{HASIL DAN PEMBAHASAN \\ Letak Geografi Teluk Prigi}

Kabupaten Trenggalek terletak di Propinsi Jawa Timur. Kabupaten ini terletak di antara koordinat $111^{\circ} 24^{\prime}$ dan $112^{\circ} 11^{\prime}$ BT dan di antara $7^{\circ} 63^{\prime}$ dan $8^{\circ} 34^{\prime}$ LS. Kabupaten Trenggalek di bagian utara berbatasan dengan wilayah Kabupaten Tulungagung dan Ponorogo, di bagian timur dengan Kabupaten Tulungagung, di bagian barat dengan Kabupaten Ponorogo dan Pacitan, sedangkan di bagian selatan berbatasan dengan Samudera Hindia (BPS Kab Trenggalek, 2000). Luas wilayah Kabupaten Trenggalek 120.532 .950 Ha terdiri dari $60 \%$ pegunungan dan $40 \%$ dataran rendah. (Laporan Dinas Kelautan Kab Trenggalek, 2002:2). Kabupaten Trenggalek memiliki tiga teluk yakni Teluk Prigi, teluk Munjungan, dan Teluk Panggul. Dari ketiga teluk tersebut, Teluk Prigi merupakan teluk yang paling aman untuk bersandarnya kapal-kapal dari terjangan ombak Samudera Hindia. Kondisi Teluk Prigi merupakan daerah perairan yang terlindung dengan kedalaman rata rata 9-35 meter. Produktivitas di Teluk Prigi cukup tinggi, banyaknya plankton sebagai makanan bagi ikan-ikan pelagis yang pola hidupnya bergerombol. Teluk Prigi juga merupakan daerah perikanan penghasil ikan-ikan pelagis kecil $(56,8 \%)$ yang potensial dan dapat dimanfaatkan sebagai umpan ikan hidup seperti ikan-ikan lemuru, layang, tembang dan slengseng (Laporan Tahunan, 1994:1).

\section{Modernisasi Alat Tangkap}

Modernisasi alat tangkap dipengaruhi hasil difusi pihak luar (Arif Satria,2002:48). Modernisasi di bidang teknologi penangkapan ikan di Prigi dipengaruhi oleh nelayan andon ${ }^{2}$ dari Madura dan Bugis. Budaya mboro (Jawa) atau ngandon (Madura), adalah kebiasaan nelayan dalam melakukan migrasi musiman untuk melakukan penangkapan ikan ke lokasi yang jauh dari tempat tinggalnya. Adanya interaksi nelayan lokal dengan nelayan luar Prigi mendorong terjadinya adaptasi teknologi (Masyuri,1996:40).

Berdasarkan jenis alat tangkap sejak tahun 1976, nelayan di Teluk Prigi dibagi menjadi dua yaitu nelayan modern atau nelayan maju dan nelayan tradisional. Nelayan modern adalah nelayan yang mengoperasikan alat tangkap purse seine dan gill net. Wilayah operasi penangkapan nelayan modern yang menggunakan alat tangkap purse seine dan gill net dioperasikan di perairan lepas

\footnotetext{
${ }^{2}$ Nelayan andon adalah nelayan yang melakukan kegiatan penangkapan ikan di laut dengan menggunakan kapal perikanan berukuran tidak lebih dari 30 Gross Tonnage (GT) atau mesinnya berkekuatan tidak lebih dari 90 daya kuda (DK) dengan daerah penangkapan yang berubah ubah atau berpindah pindah sehingga nelayan tersebut berpangkalan atau berbasis sementara waktu atau dalam waktu yang relatif lama di pelabuhan perikanan luar daerah asal nelayan tersebut. (Keputusan Menteri Kelautan dan Perikanan Nomor :Kep.13/MEN/2004, tentang Pedoman Pengendalian Nelayan Andon Dalam Rangka Pengelolaan Sumberdaya Ikan)
} 
pantai berjarak 4 mill pada jalur II yaitu 3-7 mill dari titik surut terendah. Nelayan tradisional merupakan nelayan yang mengoperasikan jenis pukat pantai/jaring tarik dan pancing ulur dengan jarak wilayah operasi penangkapan ikan sekitar 1-3 mill pada jalur I dari titik surut terendah (Laporan Tahunan, 1992:4).

Musim ikan di Prigi relatif singkat yaitu lima sampai tujuh bulan. Oleh karena itu alat penangkapan ikan yang efektif digunakan adalah jenis purse seine. Pada tahun 1986 alat tangkap sudah mulai dikembangkan. Balai Penelitian maupun Unit Pelaksanaan Teknis (UPT) seperti Unit Penyuluhan Penangkapan ikan (UPPI) telah melakukan uji coba pengembangan alat tangkap seperti set net, bottom long line, vertikal long line, tramel net dan payaus/rumpon. Hasilnya menunjukkan bahwa alat tangkap yang digunakan masih efektif digunakan saat musim ikan saja.(Laporan Tahunan. 1986:7).

Adapun alat tangkap pukat pantai atau lebih dikenal dengan jaring tarik telah digunakan untuk menangkap ikan sejak sekitar tahun 1930-an. Pada saat itu hanya para pegawai Pemerintah Hindia Belanda saja yang mampu memiliki. Bahan untuk membuat alat tangkap tersebut masih sederhana. Bahannya terbuat dari benang kapas dicampur dengan getah bakau pada bagian jaringnya, dan tali penarik terbuat dari penjalin dengan daya awet alat yang hanya dapat mencapai kurang lebih dua tahun (https://fiqrin.wordpress.com/artikel-tentang-ikan/pukat-pantai/ dikunjungi pada tanggal 12 Maret 2017). Jaring yang digunakan untuk menangkap ikan disebut dengan lulup, yang terbuat dari kulit batang pohon waru. Pohon ini banyak tumbuh di hutan sekitar Teluk Prigi (Khoirun, 2018:61). Alat tangkap pukat pantai dianggap efektif untuk dioperasikan pada saat tidak musim ikan Laporan Tahunan,2000:4).

Pada tahun 1970-an, penangkapan ikan di Teluk Prigi dilakukan di dekat pantai dengan menggunakan alat tangkap tradisonal. Perahu yang digunakan untuk menangkap ikan hanya digerakkan oleh tenaga manusia. Perahu jenis ini oleh nelayan disebut dengan perahu konting (Khoirun, 2018, 61). Perahu konting merupakan tipe perahu jukung, yaitu tipe perahu kecil, yang dibuat dari sebatang pohon utuh kemudian dibentuk menjadi perahu(Masyuri,1996:42). Perahu jukung digunakan menangkap ikan di dekat pantai dan nelayan tidak lebih dari empat orang (Sutejo, Dinamika Kebijakan Tentang Perikanan Dan Transformasi Budaya Nelayan Pantai Utara Jawa (http://ejournal.undip.ac.id/index.php/sabda/article/view/13297 )). Selain perahu konting, nelayan juga menggunakan perahu gethek. Gethek terbuat dari bambu dengan kapasitas empat orang.

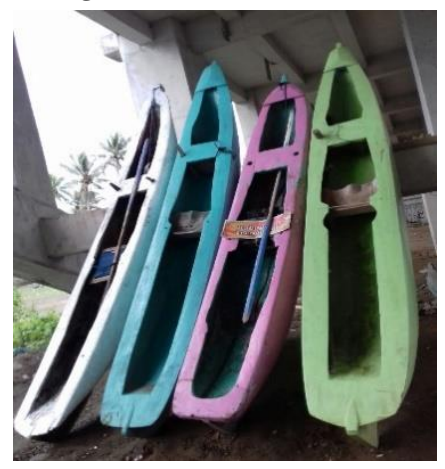

Gambar 1.1 Parahu Konting tampak dari depan. Perahu ini dipakai nelayan pancing Teluk Prigi pada tahun 1978-2004.

Sumber Khoirun Nikmah, Perkembangan Pelabuhan Perikanan Prigi dan Dampaknya Terhadap Kehidupan Sosial Ekonomi Nelayan Desa Tasikmadu, Kecamatan Watulimo, Kabupaten Trenggalek Tahun 19782004 (Tesis Program Pascasarjana Ilmu Sejarah UNDIP, tesis tidak diterbitkan , 2018) hlm 62.

Pada tahun 1976 nelayan andon yang berasal dari Bugis Sulawesi, bernama H. Mading, datang ke Prigi dengan membawa delapan kapal purse seine. Saat itu kapal jenis ini oleh nelayan Prigi disebut kapal slerek, yang berarti diseret dengan jaring. Kapal purse seine ini kapasitasnya untuk 12 orang dengan mesin 12 PK. Perahu purse seine sudah menggunakan motor tempel dengan kapasitas 5-10 GT. Motor tempel oleh nelayan Prigi disebut kapal jhonson, yaitu merujuk pada merek motor tempel jhonson (Khoirun, 2018:62). Pada tahun 1978 aktivitas nelayan dalam menangkap ikan menggunakan dua kapal purse seine. Di bagian utama kapal, dikendalikan oleh nahkoda, sedangkan di kapal bagian belakang digunakan sebagai tempat menyimpan jaring dan 
pelampung. Nelayan berangkat pada waktu sore dengan menempuh perjalanan sekitar tiga jam. Nelayan tiba di TPI pada pagi hari (Budi Siswanto, 2008:8).

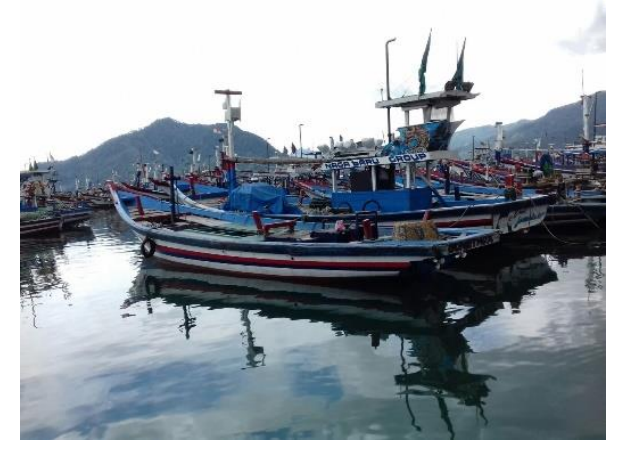

Gambar 2.2 Kapal purse seine, menggunakan mesin yang ditanam di dalam kapal dan motor tempel. Kapal ini digunakan nelayan purse seine dengan model seperti gambar di atas sejak tahun 1980-an

Sumber : Khoirun Nikmah, Perkembangan Pelabuhan Perikanan Prigi dan Dampaknya Terhadap Kehidupan Sosial Ekonomi Nelayan Desa Tasikmadu, Kecamatan Watulimo, Kabupaten Trenggalek Tahun 1978-2004 (Tesis Program Pascasarjana Ilmu Sejarah UNDIP, tesis tidak diterbitkan , 2018) hlm 63.

Pada tahun 1980, nelayan tradisional pancing ulur telah menggunakan perahu yang panjangnya 11 meter dengan lebar 2 meter. Setiap perahu dioperasikan oleh empat orang nelayan. Tiga nelayan bertugas sebagai pandega atau pendayung dan satu orang sebagai juru mudi atau nahkoda. Tahun 1980-an jumlah pekerja bertambah menjadi enam orang, satu orang menjadi mandor dan lima pendayung. Perahu pancing ulur ini digerakkan dengan tenaga manusia. Dalam perkembangannya, sekitar tahun 1982, nelayan mulai menggunakan motor tempel. Pada tahun 1992 motor tempel mulai massif digunakan oleh nelayan. Adapun perahu yang digunakan pada periode ini adalah model perahu jukung. Pada tahun 2000 perahu yang digunakan untuk menangkap ikan ukurannya semakin besar dengan panjang 3 meter kali 12 meter (Khoirun, 2018: 63-64). Pada tahun 1979 hingga tahun 2004. Alat tangkapnya terdiri dari sembilan jenis yakni purse seine, gill net, pukat pantai/jaring tarik, bagan apung, pancing konting/hand line, payang, trammel net, dan pancing tonda. ${ }^{3}$

Dari tahun ke tahun jumlah alat tangkap purse seine terus mengalami peningkatan. Penggunaan alat tangkap gill net pada tahun 2004 mengalami penurunan menjadi 17 unit. Penggunaan jaring tarik paling banyak pada tahun 2004, yaitu 40 unit. Meskipun alat tangkap jaring tarik tergolong alat tangkap tradisonal, tetapi penggunaanya masih dipertahankan. Penggunaan alat tangkap bagan apung dari tahun 1979-2004 mengalami penurunan. Alat tangkap ini pada tahun 1979 sebanyak 20 unit, dan pada tahun 2004 nelayan sudah tidak menggunakan alat tangkap bagan apung. Hal ini disebabkan karena bagan apung dianggap kurang efisien dipakai di Teluk Prigi (Khoirun, 2018: 65).

Upaya meningkatkan produksi dilakukan dengan cara merubah beberapa ukuran alat tangkap purse seine, yaitu yang semula ukuran panjang 300 meter, lebar 22 meter menjadi panjang 400500 meter dengan ukuran lebar tetap. Beberapa unit alat tangkap purse seine dirubah menjadi panjang 700 meter dan lebar 30 meter. Selain itu, di perairan ini juga hadir nelayan andon dengan alat tangkap gill net, payang, dan mini longline/prewe (Laporan Tahunan, 1992:5).

\footnotetext{
${ }^{3}$ Purse seine merupakan alat penangkapan ikan yang berbentuk kantong dilengkapi dengan cincin dan tali purse line. Gill net adalah purse seine ukuran kecil. Pukat pantai atau jaring tarik merupakan salah satu jenis alat tangkap berbentuk seperti pukat kantong. Bagan apung adalah alat tangkap untuk ikan palagis. Payang merupakan alat tangkap berbentuk pukat kantong untuk menangkap gerombolan ikan di permukaan. Trammel net adalah alat untuk menangkap udang, disebut juga jaring gondrong. Wawancara dengan Bapak Sarji, 14 April 2017.
} 
Pada tahun 2000, untuk meningkatkan produksi perikanan, dilakukan modifikasi terhadap ukuran jaring purse seine. Jaring ini ukurannya disesuaikan dengan jenis ikan yang akan ditangkap. Jaring purse seine terdiri dari tiga ukuran. Pertama, jaring jenis ikan kecil (dioperasikan pada malam hari), ukuran mata jaring 3/4" dan 1" panjang 500-600 m lebar 40-50 m, produksi ikan yang didaratkan adalah lemuru, layang, selengseng, ekor merah, dan kembung. Kedua, jaring jenis ikan besar (dioperasikan pada siang hari) dengan ukuran mata jaring 1" dan 2" panjang 700-600 m lebar 50-65 m, produksi ikan yang didaratkan : tonngkol, tuna, kuwe, dan cakalang. Ketiga, jaring ikan kecil dan besar (dioperasikan pada siang hari dan malam hari) dengan ukuran mata jaring 3/4", 1" dan 2" panjang 700-800 lebar 50-65 m. Produksi yang didaratkan yaitu ikan ekor merah, slengseng, tongkol, tuna, cakalang, dan kembung (Laporan Tahunan, 2000).

Pada tahun 2004 muncul alat tangkap pancing tonda dan trammel net. Untuk membantu menangkap ikan, pancing tonda menggunakan rumpon. Pada tahun 2004 PPN Prigi juga melakukan pengadaan rumah pondokan ikan (rumpon) dalam rangka optimalisasi penangkapan ikan (Laporan Tahunan, 2005:4). Tujuan pemasangan rumpon di suatu perairan adalah untuk memikat ikan agar mau singgah, beristirahat, berkumpul, atau terkonsentrasi di sekitar rumpon. Melalui cara ini, maka akan dapat mempermudah nelayan dalam menentukan daerah penangkapan ikan (fishing ground). Selain itu, dapat memastikan daerah penangkapan ikan secara tepat. Melalui metode ini, waktu dan biaya operasi penangkapan bisa diprediksi secara akurat, sehigga usaha penangkapan ikan akan bisa menjadi lebih efektif dan efisien (Sulaeman, 2008:1).

Teknologi penangkapan ikan di Prigi didukung oleh perkembangan armada yang digunakan. Jumlah armada di Teluk Prigi fluktuatif. Armada yang digunakan di Prigi digolongkan menjadi tiga jenis yakni kapal motor, motor tempel, dan perahu tanpa motor. Kapal motor adalah kapal yang bagian mesinnya sudah ditanam di dalam kapal. Kapal motor tempel adalah kapal yang sudah menggunakan mesin tetapi mesinnya dapat dibongkar pasang. Perahu tanpa motor adalah perahu yang sama sekali tidak menggunakan mesin (Khoirun, 2018: 66).
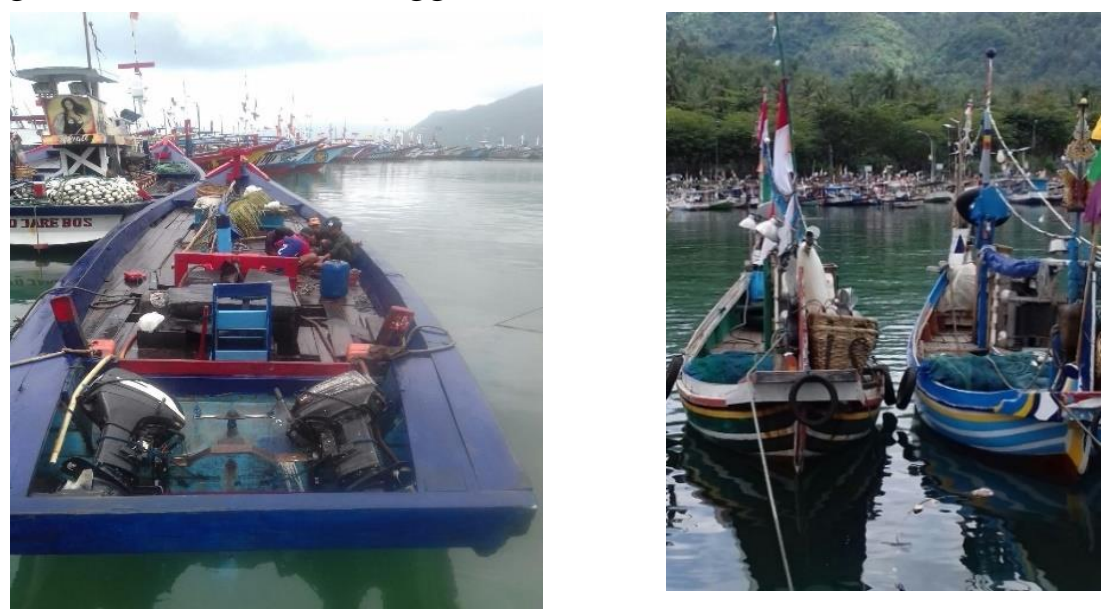

Gambar 4.3 : Motor tempel pada alat tangkap purse seine dan payang, digunakan nelayan mulai tahun 1980-2006.

Sumber : Khoirun Nikmah, Perkembangan Pelabuhan Perikanan Prigi dan Dampaknya Terhadap Kehidupan Sosial Ekonomi Nelayan Desa Tasikmadu, Kecamatan Watulimo, Kabupaten Trenggalek Tahun 1978-2004 (Tesis Program Pascasarjana Ilmu Sejarah UNDIP, tesis tidak diterbitkan , 2018) hlm 67.

Perkembangan jumlah armada di Prigi mengalami naik turun dari tahun 1978-2004. Hal ini disimpulkan karena banyaknya nelayan andon yang singgah dan pergi ke wilayah Prigi sehingga armada yang tercatat menjadi berkurang. Jika musim ikan nelayan andon banyak yang mencari ikan di Prigi, begitu pula sebaliknya. Kerusakan armada juga dapat menyebabkan berkurangnya jumlah armada. Selain itu nelayan yang tidak memiliki modal akhirnya tidak dapat mengoperasikan perahunya sehingga berdampak pada berkurangnya armada (Khoirun, 2018: 67$68)$.

Kapal motor pada tahun 1979 hanya berkapasitas 10-20 GT. Pada tahun 1990 nelayan andon membawa kapal motor dengan kapasitas 20-30 GT. Armada baru yang dipakai nelayan andon, mempengarui nelayan Prigi untuk memiliki kapal berkapasitas 20-30 GT. nelayan lokal pada tahun 1993 memiliki kapal berkapasitas 20-30 GT dengan jumlah 65 unit. 
Motor tempel sudah banyak digunakan nelayan Prigi sejak 1979 dengan jumlah 210 unit. Motor tempel digunakan untuk alat tangkap payang, gill net, prawe, dan jaring tarik. Penggunaan motor tempel menunjukkan penurunan dikarenakan adanya kerusakan pada motor tempel, kemudian singkatnya musim ikan di Perairan Prigi. Perahu tanpa motor digunakan nelayan tradisional seperti nelayan pancing. Pemakaian perahu tanpa motor mengalami penurunan dari tahun ketahun. Hal ini karena nelayan bergeser ke teknologi yang lebih modern seperti motor tempel (Khoirun, 2018: 68).

\section{Pengaruh Modernisasi Alat Tangkap}

Masyarakat nelayan Prigi memiliki jaringan relasi patron-klien yang sangat kuat, beragam, dan mencakup banyak segi kehidupan sosial ekonomi. Relasi demikian terbentuk karena konsekuensi dari karakteristik pekerjaan sebagai nelayan serta kondisi lingkungan dan sifat sumber daya alam yang menjadi basis ekonomi kehidupan nelayan. Ciri-ciri dari kerakteristik ini berupa ketersediaan sumber daya perikanan yang bergantung pada fluktuasi musim, sifat sumberdaya perikanan yang bergerak dinamis karena pengaruh perubahan alam dan lingkungan, dan berbagai resiko yang terjadi dalam kegiatan penangkapan (Kusnadi, 2007:9). Pola-pola relasi sosial patron-klien antara nelayan pemilik dan nelayan buruh ditandai dengan hubungan kerja dan pertukaran sumber daya ekonomi (Kusnadi, 2007:11).

Hubungan kerja pada tahun 1980an nelayan Teluk Prigi masih sederhana. Hubungan kerja hanya terdiri dari nelayan juragan atau pemilik kapal dengan ABK. Hubungan kerja antar nelayan pada umumnya dilakukan berdasarkan hubungan tolong-menolong, kekerabatan, dan kepercayaan antara pemilik perahu atau juragan darat dengan pekerja (Khoirun, 2018:69). Hubungan kerja yang demikian terjadi pada nelayan modern maupun nelayan tradisioanl.

Kapal purse seine pada tahun 1980-an dalam sekali berlayar membawa 12 orang. Hubungan kerja pada kapal purse seine terdiri dari juru mudi (nahkoda), tukang batu, tukang plampung, tukang tarik kolor (penarik jaring), tukang nyelam (menyelam) dan tukang mantho (melihat) ikan (Khoirun, 2018:70). Pada perkembangannya tahun 1990-an perekrutan ABK tidak hanya sebatas berdasarkan hubungan kekeluargaan saja, ABK direkrut oleh juragan dengan mempertimbangkan ketrampilan, pengalaman, keberanian, dan keahlian tertentu yang dimiliki oleh nelayan. Seorang juragan harus pandai dalam memilih anak buahnya, terutama pemilihan tenaga kerja untuk dijadikan juru mudi. Juragan merekrut juru mudi atas dasar kemampuan menaklukan laut selatan yang terkenal ganas.

Pada tahun 1990-2001 hubungan kerja pada nelayan purse seine lebih komplek. Dalam sekali berlayar kapal purse seine membawa 25 orang. Hubungan kerja pada nelayan purse-seine terdiri dari juragan darat (pemilik perahu dan alat tangkap), juragan laut (nahkoda), ABK, buruh pelabuhan (tenaga angkut keranjang ikan dan penunggu keranjang ikan), dan bakul ikan (tengkulak). Hubungan kerja nelayan tradisional seperti pukat pantai yakni juragan darat, ABK, pekerjaan sebagai pengurus kapal yang bertugas mewakili ABK pada saat lelang hasil tangkapan dan buruh (penarik jaring) (Khoirun, 2018:70).

Pada tahun 2001, juragan pada kapal purse seine saling bersaing untuk mendapatkan juru mudi yang handal. Juru mudi yang handal merupakan kebanggaan tersendiri bagi nelayan. Juru mudi yang tidak mendapat bonus yang besar, akan berpindah ke juragan lain, namun ada yang tetap setia kepada juragannya. Juragan akan mengangkat ABK lain untuk menggantikan juru mudi, misalnya tukang mesin/tukang jhonshon. Persaingan antar juragan menjadi salah satu faktor renggangnya solidaritas dalam komunitas juragan dan nelayan. Renggangnya solidaritas internal komunitas juragan dengan $\mathrm{ABK}$ kapal purse seine menyebabkan terjadinya pencurian ikan atau esekan (Budi Siswanto, 2008:29-30).

Esekan yang berorientasi ekonomi pertama kali muncul pada tahun 1978/1979 sebagai transaksi kecurangan juragan. Tradisi ini diawali oleh Kabul Supratman seorang nelayan lokal. Kabul sebagai tukang jhonshon di kapal purse seine dan menemukan kecurangan juragan antara lain jumlah bobot ikan hasil tangkapan nelayan dalam setiap satu bulan menurut catatan nelayan lebih besar daripada catatan juragan, juragan menjumlah total biaya operasinal yang jauh lebih besar daripada catatan ABK (Budi Siswanto, 2008:24). Pada tahun 2001-2004 esekan semakin tidak terkendali. Para ABK ini berdalih bahwa juragan telah banyak melakukan kecurangan karena bagi hasil tidak sesuai dengan jumlah ikan yang ditangkap, sehingga wajar jika nelayan mengambil ikan dengan istilah esekan (Khoirun, 2018:71). 
Nelayan dapat menentukan kapan saatnya melaut dan musim ikan. Masa melaut nelayan ditentukan oleh rotasi bulan. Pada saat terang bulan, nelayan libur melaut dan memanfaatkan waktu tersebut untuk memperbaiki sarana penangkapan (perahu jaring) yang rusak. Kegiatan awal melaut dilakukan sesudah masa terang bulan berakhir (Kusnadi, 2007:31-32). Ikan tangkapan nelayan dijual dalam kondisi segar atau hasil olahan, seperti pemindangan dan pengasapan.

Juragan-juragan pemilik perahu dengan sendirinya memiliki posisi yang kuat di kalangan nelayan. Mereka biasanya menguasai penjualan ikan yang mereka hasilkan, lebih-lebih pada saat perdagangan ikan segar meningkat (Masyuri, 1995:190). Karakteristik seperti ini mempengaruhi tingkat pendapatan nelayan, dari yang tidak memperoleh pendapatan sama sekali hingga yang memperoleh penghasilan dalam jumlah besar (Kusnadi, 2007: 9). Sistem bagi hasil pada nelayan modern jenis purse seine dari tahun 1978-2006 tidak mengalami perubahan. Sistem bagi hasilnya yakni, hasil kotor dipotong biaya operasional menjadi hasil bersih. Hasil bersih, kemudian dibagi tiga. Dua pertiga bagian untuk pemilik kapal atau juragan darat, satu pertiga bagian untuk ABK dan nahkoda. Nahkoda diberi tambahan $10 \%$ dengan hitungan dua pertiga dikali $10 \%$ milik juragan darat (Khoirun, 2018: 72).

Praktik bagi hasil di kalangan nelayan purse seine diwarnai saling curiga antara ABK dengan juragan. ABK merasa pembagian bagi hasil tidak adil. Jumlah bobot ikan hasil tangkapan nelayan dalam setiap satu bulan menurut catatan ABK lebih besar daripada catatan juragan. Sedangkan juragan bersikeras bahwa, biaya operasional yang dicatat juragan lebih besar. Keadaan ini berakibat $\mathrm{ABK}$ mengambil ikan sebelum totalan. Keadaan seperti ini disebut esekan. Esekan semakin besar dan berbau kriminal. Juragan merasa dirugikan oleh tindakan ABK (Budi Siswanto, 2008:23-24). Esekan ini berdampak pada keengganan nelayan purse seine membayar retribusi lelang. Juragan purse seine menuding esekan terjadi karena sistem lelang di TPI tidak berlaku. Nelayan menganggap TPI adalah "Tempat Penimbangan Ikan" bukan Tempat Pelelangan Ikan.

Sistem bagi hasil nelayan modern berbeda dengan nelayan tradisional. Nelayan tradisional seperti jaring tarik atau pukat pantai, menggerakkan perahu dengan empat orang pendayung. Juragan perahu selalu menyiapkan dana kontan dalam sekali melaut. Pada tahun 1961 upah penarik jaring pukat pantai sebesar lima rupiah. Lima rupiah sudah bisa dibelikan bahan pokok dan keperluan dapur (Khoirun, 2018:72). Sistem bagi hasil pada nelayan pukat pantai yakni dua pertiga untuk juragan atau pemilik perahu dan satu perempat untuk ABK. Pada saat di bibir pantai jaring ditarik 20-30 orang. Jika tidak mendapatkan hasil tangkapan, juragan perahu harus tetap membayar penarik jaring. Sistem bagi hasil pada nelayan jaring tarik tidak mengalami perubahan sejak tahun 1978-2004. Tahun 1980-an upah penarik jarik sebesar Rp. 750,00. Uang tersebut bisa ditukar dengan harga bahan pokok keperluan rumah tangga, seperti beras dan lauk pauk. Para penarik jaring selain mendapat upah Rp. 750,00 juga mendapat makan dan minum. Jika tangkapan ikan melimpah dalam satu hari penarik jaring bisa menarik sebanyak dua kali, dan para juragan jaring tarik tidak menambah upah (Khoirun, 2018:73)

Sistem bagi hasil pada nelayan tradisional seperti pancing ulur yakni satu pertiga untuk biaya operasional (membeli es, BBM), dan dua pertiga untuk ABK (juragan dan nahkoda). Jumlah nelayannya dua sampai tiga orang dalam sekali melaut. Sistem bagi hasil pada jaring payang dan trammel net atau jaring pithil tidak jauh berbeda dengan sistem bagi hasil pancing ulur. Sistem bagi hasil nelayan pancing ulur tidak ada perubahan dari tahun 1978-2004 (Khoirun, 2018:73).

\section{PENUTUP}

Modernisasi adalah suatu yang lumrah bagi pemajuan masayarakat. ). Modernisasi di bidang teknologi penangkapan ikan di Prigi dipengaruhi oleh nelayan andon dari Madura dan Bugis. Adanya interaksi nelayan lokal dengan nelayan luar Prigi mendorong terjadinya adaptasi teknologi. Berdasarkan jenis alat tangkap sejak tahun 1980-an, nelayan di Teluk Prigi dibagi menjadi dua yaitu nelayan modern atau nelayan maju dan nelayan tradisional. Nelayan modern adalah nelayan yang mengoperasikan alat tangkap purse seine dan gill net. Nelayan tradisional merupakan nelayan yang mengoperasikan jenis pukat pantai/jaring tarik dan pancing ulur. Modernisasi alat tangkap bagi nelayan Prigi memeberikan dampak pada perubahan hubungan kerja, dan perubahan bagi hasil tangkapan nelayan. Adanya modernisasi menyebabkan perubahan yang mencolok pada nelayan purse seine. Praktik bagi hasil di kalangan nelayan purse seine diwarnai saling curiga antara ABK dengan juragan. ABK merasa pembagian bagi hasil tidak adil. Jumlah bobot ikan hasil tangkapan nelayan dalam setiap satu bulan menurut catatan ABK lebih besar daripada catatan juragan. Sedangkan juragan bersikeras bahwa, biaya operasional yang 
dicatat juragan lebih besar. Keadaan ini berakibat ABK mengambil ikan sebelum totalan. Keadaan seperti ini disebut esekan.

\section{DAFTAR PUSTAKA}

Badan Pusat Statistik, Tenggalek Dalam Angka Tahun 2000.

Departemen Pertanian Direktorat Jendral Perikanan, Laporan Tahunan Pelabuhan Perikanan Prigi tahun 1983-2007.

Dinas Kelautan dan Perikanan Kabupaten Trenggalek, Laporan Tahunan Dinas Kelautan Dan Perikanan Kabupaten Trenggalek 2002-2003.

https://fiqrin.wordpress.com/artikel-tentang-ikan/pukat-pantai/ dikunjungi pada tanggal 12 Maret 2017.

Kusnadi, Jaminan Sosial Nelayan ( Yogyakarta: LKIS, 2007)

Kusnadi, Strategi Hidup Masyarakat Nelayan (Yogyakarta: LKIS, 2007)

Martasuganda, Sulaeman. Rumpon-Rumah Pondokan Ikan/Fish Aggregation Device (Departemen Pemanfaatan Sumberdaya Perikanan dan Kajian Sumberdaya Pesisir dan Lautan: Institut Pertanian Bogor, 2008)

Masyhuri. Menyisir Pantai Utara. Usaha dan Perekonomian Nelayan di Jawa dan Madura 18501940. ( Yogyakarta: Yayasan Pustaka Nusantama, 1995).

Nikmah Khoirun, Perkembangan Pelabuhan Perikanan Prigi dan Dampaknya Terhadap Kehidupan Sosial Ekonomi Nelayan Desa Tasikmadu, Kecamatan Watulimo, Kabupaten Trenggalek Tahun 1978-2004 (Tesis Program Pascasarjana Ilmu Sejarah UNDIP, tesis tidak diterbitkan , 2018)

Pranoto, W Suhartono, Teori dan Metodologi Sejarah (Yogyakarta: Graha Ilmu, 2010).

Satria, Arif, Pengantar Sosiologi Masyarakat Pesisir (Jakarta:PT Pustaka Cidesindo, 2002).

Siswanto, Budi. Kemiskinan dan Perlawanan Kaum Nelayan (Malang: Laksbang Meditama, 2008)

Susilo, Edi dkk. "Kajian Struktur Sosial Masyarakat Nelayan di Ekosistem Pesisir". Jurnal WACANA Vol. 13 NO.2. (Jurusan Sosial Ekonomi FPIK Universitas Brawijaya, 2010)

Sutejo K Widodo, Dinamika Kebijakan Tentang Perikanan Dan Transformasi Budaya Nelayan Pantai Utara Jawa (http://ejournal.undip.ac.id/index.php/sabda/article/view/13297 ) diunduh tanggal 29 Oktober 2017.

Weiner, Myron. Modernisasi Dinamika Pertumbuhan (Voice of Amerika Forum Lectures, 1961)

Widodo, Sutejo K. Ikan layang Terbang Menjulang (Semarang: Badan Penerbit Universitas Diponegoro, 2005).

Zuhdi, Susanto. Nasionalisme Laut dan Sejarah (Depok: Komunitas Bambu,2014). 